\title{
Organizational Governance, Board of Directors, and the Influence of Context in Emerging Markets
}

\author{
Madi M Almadi ${ }^{1}$ \\ ${ }^{1}$ Madi Almadi, Melbourne, VIC, Australia \\ Correspondence: Madi M Almadi, Madi Almadi, Melbourne, VIC, Australia. E-mail: madi.almadi@rmit.edu.au
}

Received: August 3, 2015

Accepted: October 23, 2015 Online Published: November 25, 2015

doi:10.5539/ijbm.v10n12p116

URL: http://dx.doi.org/10.5539/ijbm.v10n12p116

\begin{abstract}
This paper aims to build corporate governance theory to inform company success in the context of emerging markets. Success for a company listed in an emerging market is contingent on being able to effectively manage a range of business, economic, social and political considerations unique to that emerging country. This paper explains the significance of incorporating context with corporate governance systems to inform how can organizational governance and board of directors affect firm performance. Theory developed in the context of emerging markets provides the basis for more widely applicable emerging stock market insight into theory of context and practice of corporate governance.
\end{abstract}

Keywords: organizational governance, board of directors, theory in context, firm performance, emerging markets

\section{Introduction}

There has been substantial focus in recent years on the topic of corporate governance, especially in emerging markets. Much of the interest has been on how well corporate governance systems in functioning in emerging markets countries. Is the two-tiered board of directors corporate governance system best? or the AngloAmerican single-tiered board of directors? Nevertheless, much less discussion of corporate governance institutions in emerging markets has taken place (Allen et al., 2005; Marquis \& Raynard, 2015). Hence, this paper assesses some of the issues that occur regarding corporate governance systems, focusing particularly on the influential institutional settings relevant to developing nations. Essential to any debate of corporate governance is the subject of how a particular set of institutions mitigates any Western developed form of corporate governance. Indeed, emerging markets economies, governments, businesses and societies have unique characteristics defer significantly from their advanced counterparts. Notably difference in market freedom and competition which usually in the hand of few wealthy commercially active families, lack of economic diversity, an influential public service, concentration on infrastructure projects, the socially and/or politically driven derived influence exploited commercially (The World Bank, 2009). These unique characteristics in emerging markets have an influence on past, and still current, and predicted to be affect future corporate governance practices. To make the matter more complex - hence interesting to investigate -, there are no standard practices on corporate governance and board of directors in emerging markets, as there are different social, cultural, and political elements in each particular country context (Wright et al., 2005). In comparison with advanced markets, emerging markets do not have well-established and mature business institutions, legal statutes, legal systems and infrastructure to help to manage corporate governance challenges (Claessens \& Yurtoglu, 2013).

Against this background, the purpose of this conceptual paper is to better understand corporate governance theory and practice in the unique business, economic and social context of emerging markets (Note 1). Much of the corporate governance research conducted within that context has so far mainly focused on investigating corporate governance practices from a Western Anglo-American perspective, neglecting the institutional settings unique to emerging markets (Xu \& Meyer 2013). Producing theory feedback loops through advanced-market developed imperatives together with discounting or limitedly acknowledging the influence of weakly and largely dysfunctioning formal institutions would result in invalid and misleading diagnosis of corporate governance in emerging markets (Fan et al., 2011; Krause et al., 2014). Therefore, this paper advances knowledge of corporate governance in emerging markets by making two critical contributions. First, drawing on agency, hegemony, institutional, resource dependence and stewardship theory, a multi-theoretic perspective is given to explaining 
the relationship between key aspects of organizational governance, board of directors and their impact on firm performance in emerging markets context. A series of research propositions are developed. Second, reflecting on the insights gained from connecting a multi-theoretical corporate governance perspective to theory development in emerging markets, the discussion considers theoretical and practical implications to emerging markets that may be relevant and insightful to policy makers and practitioners. Thereby contributing to the practice of corporate governance worldwide.

The research questions that inform this paper are as follows: What are the most favourable choices for board of director with a view to financial performance in emerging markets? What are the implications of insights on governance organization, board of directors, and firm performance in emerging markets and how they defer among emerging markets? The remainder of this manuscript is organised as follows. The second section reviews related literature in corporate governance and emerging markets. In the third section the paper develops research propositions and a conceptual model, followed fourth by the discussion and conclusion section including theoretical implications, practical implications, limitations, future research, and concluding remarks.

\section{Theoretical Background}

Corporate governance scholars have acknowledged that there has been little systematic evidence of board composition effect on firm performance. Withers et al. (2012) and Johnson et al. (2013) argue that those conclusions are probably the result of reliance on a single or two theoretical approaches. To gain broader insights into this phenomenon in the emerging markets context, the theoretical background of this paper will draw on agency, hegemony, resource dependence, and stewardship theory. This will be supplemented with other insights related to the emerging markets context including trends in business, economy and society.

Agency theory posits that directors are agent representing the shareholders, responsible for overseeing and the activities of management (Jensen and Meckling 1976; Johnson et al., 1996; Boyd et al., 2011). The theory primarily recognizes that independent directors as a key control instrument that prevent the principal-agent conflicts to occur (Karolyi, 2012). An additional view of agency theorists is that the main value of institutional investors (e.g. government departments, insurance companies) is to improve the board's monitoring mechanisms. Johnson et al. (1996) suggest that many private institutional investors, such as private banks and insurance companies can face potential conflicts of interest however public pension funds 'are virtually free of such conflicts' (p. 415). Board composed of active independents and institutional investors, especially public ones, would strengthen the control mechanisms of the board, thereby enhancing firm performance (Withers et al., 2012). However, Johnson et al. (2013) argue that the theory suffers from the lack of considerations to significant social and behavioural elements, importantly relevant to emerging markets. Thus development of research insight supported by other theoretical approaches is recommended.

In addition, Hegemony theory implies that individuals with prestigious status in society dominate the board of the directors (Burris, 2005). Such domination means the elimination or reduction of the influence of other social groups, and hence the interests of the elites are protected (Useem, 1984). The theory further advocates that directorial interlock is the main instrument for these directors to maintain and extend their power and status (Burris, 2005). Given their influence, the theory suggests that these directors can benefit the firm and have a mutual benefit with the rest of shareholders. Precisely, Huse et al. (2011) specify that outside directors with prestige or status can reduce market risks by horizontal integration (i.e. when some competitors are connected together through interlocking directorates), or vertical coordination (i.e. when suppliers or customers are invited to be board members). Moreover, due to their influential interlocks, outside directors with high status can provide access to vital resources with favourable financial consequences for the firm (Davis et al., 2003). However, hegemony theory is criticized for ignoring the changing structure of firm ownership. Zahra and Pearce (1989) argue that the fact that some individual investors still own a sizable share of company equity, private and public institutional investors have become the leading force in modern markets. Therefore, exclusive reliance on the theorized power of the elite in the board is not justified given the increasing influence of public and private institutional investors. Other governance theories would have the potential to yeild further insights.

Furthermore, where outside directors have experience and linkages relevant to the firm's external environment, resource dependency theory suggests that these directors can assist the board in securing favourable access to resources for their employers (Pfeffer, 1972; Peng, 2004). Due to their expertise and influence with the public service, institutional representative directors can assist the company in preventing costly missteps when its activities may unintentionally conflict with the interests of these agencies (Bazerman \& Schoorman, 1983). Increasing coordination with the central authorities and other businesses gives access to critical information, increases the firm's legitimacy, and improves firm performance (Hillman et al., 2000). Although resource 
dependence theory and hegemony theory have similar views on how directorial interlocks can benefit the firm, the resource dependence theory emphasizes that the board member is being selected by the corporation rather than a social class (Zahra \& Pearce, 1989). Outside directors can also offer advice and counsel regarding general management and strategic choices (Pfeffer \& Salancik, 1978). Outside directors with strong human capital affect how board members consider and evaluate management decisions. While resource dependence theory has become accepted and used in many studies, the resource role of the board has not been as thoroughly examined as it could be (Johnson et al., 2013). Accompanying resource dependence theory with other relevant theoretical approaches would enable a better understanding of the value of this theory.

It has to be noted that agency, hegemony and resource dependence are organizational theories built upon economic rationality (Perrow, 1986). On the other hand, stewardship theory largely ignores that and rather emphasises the behavioural aspects of the agent (Donaldson \& Davis, 1991). Stewardship theory proposes that executives and managers are good stewards whose motivations are aligned with the interests of shareholders (Davis et al., 1997). These executives and managers are assumed to be trustworthy, committed, well informed, are good monitors and will not misuse firm resources, and the theory advocates that one or more company executives should be appointed to the board (Coles et al., 2001; Nicholson \& Kiel, 2007). Stewardship theory opposes agency theory view in relation to the value of a majority of independent directors; stewardship theory views the presence of independent directors as neither critical nor essential (Dalton et al., 1998).

Moreover, most of the relevant literature on corporate governance has been based on advanced market studies. Mueller (2006) and Fan et al. (2011) suggest that agency, hegemony, resource dependence, and stewardship theories have been developed in the context of advanced economies, leaving little or no consideration of the unique social, political, and economic contexts presented in emerging stock markets. More importantly, previous research has largely neglected bundling contextual considerations of emerging markets with theory, and rather have deployed in parallel with it (Xu \& Meyer 2013). The lack of integration between theory and context means an accurate diagnosis of a phenomenon in emerging markets would not be achieved. According to Huse et al. (2011, p. 12), understanding the relationship between board structure and firm performance in emerging markets 'requires an explicit involvement of context that underline the premise of the research'. Such alignment remains relatively scarce (Kearney, 2012), with China taking most of the interest.

In this regard, institutional theory has become the leading theory to be aligned with when studying corporate governance issues in the context of emerging countries (Hoskisson et al., 2000). Institutions such as political, economic, social, and educational bodies affect the stock market and company practice, and influence the strategic direction of these organizations. In emerging economies, firms are often led by informal institutions such as influential families and business groups (Peng, 2004). These business arrangements can result inefficient governance standards, thereby creating weak governance environments (Wright et al., 2005). Laws that that regulate fundamental elements of corporate governance such as transparency of management to shareholders, accounting standards, and board structure are either absent or ineffective (Millar et al., 2005). Hence, firms in emerging countries tend to rely on reputation and trust as a substitute for absence of effective regulations (Allen, 2005; Xu \& Meyer, 2013).

Another consideration is that as the institutional context in emerging markets makes the enforcement of business contracts more challenging and expensive, concentrated ownership occurs as a response. Yet, this strategy can fuel the development of principal-principal conflicts (Young et al., 2008). The principal-principal problems occur when the controlling shareholders oppress minority shareholders through their presence on the board of directors (Phan, 2001). Principal-principal conflicts can negatively impact firm strategy choices, dividend policy, stock prices, and lead to the high chance of expropriation of minority shareholders (Young et al., 2008). Moreover, Peng (2004) suggests that listed companies in emerging countries are likely to be under pressure to maintain legitimacy and transparency as a response to political and public demands. As a response, he clarifies that these firms would appoint independent directors for only symbolic purposes. While these firms strategically comply with these demands, they usually subtly limit the independence of those directors (Khanna \& Thomas, 2009). For instance directors may formally appear to be independent, but their independence can be reduced for example by social links with other board members (Claessens \& Yurtoglu, 2013).

As institutions, management and learning processes in emerging countries are improving, Hoskisson et al. (2000) and $\mathrm{Xu}$ and Meyer (2013) recommend furthering corporate governance theories that were tested in advanced economies by explicitly aligning them with the distinctive social, political, and economic contexts of emerging markets. Such an approach would make a significant contribution to corporate governance literature, and could improve corporate governance practices in emerging markets (Whetten, 2009; Kearney, 2012; Mallin, 2013). Table 1 below provides a summary of representative studies that underpin the theoretical background presented 
here.

\section{Research Propositions}

Certain administrative and sociocultural elements have influenced the shaping of organizational governance practices for emerging markets listed companies. For instant, Government Representative Directors (GRDs) frequently populate the boards of companies with major infrastructure development contracts. Since theoretically-context integrated and practical frameworks that have examined the relationship between board of directors and firm performance within emerging markets limited, this paper proposes a series of research propositions (refer Figure 1 below) to make a theoretical contribution.

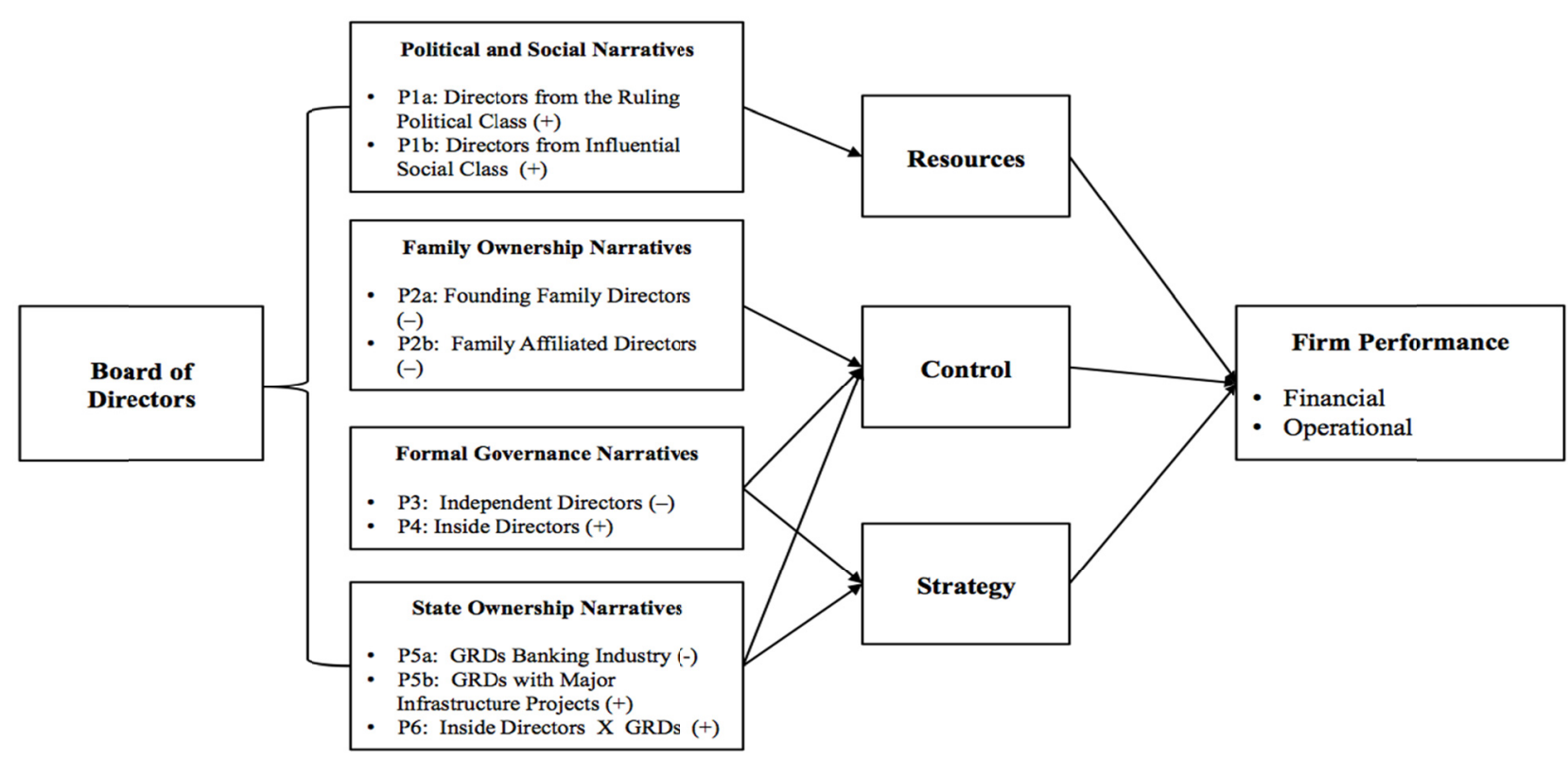

Figure 1. Multi-Theoretical model of the effect of board of directors on firm performance in emerging markets

It has been long documented that the members of the political ruling class have an influence initiating and implementing laws and regulations in emerging markets (Bray \& Darlow, 2013). Reed (2009) argues that given that emerging countries are largely one-party states, in which one single establishment directly or indirectly and yet effectively dominate the political decision, it has been observed that the political ruling class has engaged in business activities over the years some of which through participating in multi-billion dollar public projects. As a result of their influence on the political scene and involvement in the local economies, Al-Rasheed (2010) argues that the many of those have gained a major position in the business community in emerging markets. Applying hegemony theory having outside directors with political status in the boardroom with social and political influence would provide some influence to a company in relation to government decisions on allocating public projects to the business community for implementation.

Further, regionality or/and ethnicity has a significant influence in society across emerging countries (Ali, 2008). Generally, social structures in those contexts have been influenced by social status, which hence yield in granted business privileges. Also high social status frequently allied with political rulers, hence occupying senior positions in ministries and economically dominant state firms. Niblock and Malik (2007) suggest that socially privileged individuals often come second after the political class as dominant players in the political and business scenes due to the fact that socially influential figures represent a vital legitimacy and credibility mechanism to at best described controversial political rule. Hence, the presence of outside directors from influential social class in a firm can influence the government to grant that firm more favourable treatment.

In keeping with hegemony theory and institutional theory views on the ruling elite and the value of status and influence in emerging countries business and society (Davis et al., 2003; Huse et al., 2011) we propose the following:

P1a: Outside directors with from the ruling political class are positively associated with firm performance in 
emerging markets.

P1b: Outside directors from influential social class are positively associated with firm performance in emerging markets.

Since vast majority of listed firms in emerging markets are largely controlled by founding families (Solomon, 2011), most of the owners are reluctant to hand over control to non-family members due to concerns related to trust. In a study made by Oukil and Khalifah (2012) on emerging markets in the Middle East, 60 per cent of outside directors were appointed due to family connection with the major stockholders or the chairperson. As the institutional context in emerging countries makes the enforcement of business contracts more challenging and expensive, relying on trusted family members through informal social contracts can help to minimise such risk (Phan, 2001). However, agency theory argues that a majority of independent outside directors helps to avoid the principal-agent problem emerging in executive decision-making. On the other hand, family-affiliated outside director objectiveness, input to board deliberation and overall performance can be compromised due to their closeness to founding family majority shareholders (Young et al., 2008). This situation can lead to the development of principal-principal problems with minority stockholders disadvantaged compared with majority stockholders due to a lack of effective representation and influence at board level (Young et al., 2008). On balance this suggests the following:

P2a: Outside directors as the founding family with major stockholders is negatively associated with firm performance in emerging markets.

P2b: Appointment of one or more outside directors with family relationships with the firm's major stockholders is negatively associated with firm performance in emerging markets.

Agency theorists have long argued that independent directors provide more objective monitoring of management actions (Dalton et al., 1998). However, we question the independence of these directors in emerging markets firms. The reason for this scepticism is that the 'most of the controlling shareholders effectively selects directors in emerging markets' (Ezzine, 2012, p. 30). Since the owners would most likely appoint directors to help them maintain their control, the independence of those directors will be restricted and compromised. Indeed, Davies (2012) has reported that it is difficult to find independent directors across firms in emerging markets, although there has been progress in this area. He indicates that large investors strongly influence the appointment of their social and business affiliates to sit in the boardroom as independent directors. Those directors would officially appear independent but in fact they are rather delegates for the controlling shareholders. This limited independence of these directors could clear the way for the major shareholders to gain total control, resulting in the expropriation of value from minority shareholders to the majority. This situation would negatively affect the quality of board of director thinking and deliberation, limiting objective review of management performance by these directors. This compromised position for independent directors would limit their ability to perform their role (Phan, 2001). Hence:

\section{P3: Independent directors are negatively associated with firm performance in emerging markets.}

The debate on the value of inside directors on the boards of emerging markets companies is intriguing, reflecting a tension between the local business environment and more internationally accepted Anglo-American developed economy insights on the importance of the value of having one or more inside directors on the board reflecting agency, stewardship and institutional theory. A study made by Ezzine (2012) revealed that less than 10 per cent of board members in some emerging markets are insiders. This low ratio indicates controlling shareholders do not see great value in the presence of inside directors on firm board. There is an argument reflecting local business and society that inside directors have very little influence in companies due to their low representation in boardrooms. As corporate governance in vast majority of emerging markets is largely influenced by cultural norms and customs, and since founding families are extensively in control of many listed firms (The World Bank, 2009), Sarayrah (2004) argues that company boards have for a long time perceived managers as merely reporters and 'servants' (p. 68). Following this line of argument inside directors in emerging markets listed companies would add little value to organization performance.

However stewardship theorists suggest that because inside directors are better informed about the "day-to-day" work of the firm and the detail of the strategic plan they can play a more effective role in shaping the strategic direction of the firm compared with other categories of director (Coles et al., 2001; Krause et al., 2014). Foreign inside directors can also bring significant human and social capital through their business education, business training, experience, professional networks and performance track record. Foreign inside directors are valued for their developed economy business experience. Stewardship theory accepts a majority of inside directors on the board as workable due to their common objective with shareholders of the betterment of the firm. Committed 
inside directors also bring the value of their expert knowledge plus social connection to their employer (Johnson et al., 1996; Boyd et al., 2011). Agency theorists also see a role for a minority of inside directors on the board, arguing that they can add value to board deliberations through their detailed knowledge of the strategic plan and their area of executive expertise. Inside directors also have knowledge of their "day-to-day" work and interaction with the chief executive officer (CEO) on which they can keep the board advised (Johnson et al., 1996). This view reflects Anglo-American institutional expectations, which this paper argues on balance overrides local business and society views. A quality steward in an inside director role can make a difference, hence:

P4: The presence of one or more inside directors, without a voting majority of inside directors on the board, is positively associated with firm performance in emerging markets.

The value of the presence of GRDs on company boards and the quality of their contribution to board deliberation is a matter of debate.

The public sector in emerging markets is known to be highly bureaucratic. In 2012, government effectiveness among emerging countries came at the bottom of the global effectiveness list (The World Bank, 2013). This high level of bureaucracy can constrain the role and strategic insight of GRDs. An empirical study by Al-Hussain (2009) reported that banks in some emerging markets with a high level of government representation recorded the lowest return on assets and stock return ratios. This gives an indication that those directors do not play an effective nor efficient role in monitoring management and improving board deliberations in the banking industry. Hence:

P5a: The presence of GRDs is associated with below average performance in emerging markets listed banking sector companies.

In emerging countries, governments tend to own large proportion of equity in the listed firms (CMA, 2012). Governments have the power to allocate lucrative major projects. The presence of GRDs on the board does give legitimacy to the firm tendering for these lucrative contracts. Agency theorists have indicated that government representative directors can also improve control mechanisms due to their presumably high level of independence (Withers et al., 2012). Through its representative directors, the government plays a major role in monitoring management and spending on major projects. According to Al-Majed (2008) 'the state's influence is more perceptible when considering that many corporate chairmen and CEOs of companies in which the state invests have been appointed by the government' (p. 296). In this context GRDs would have a positive effect on financial performance, hence:

P5b: GRDs are positively associated with firm performance in industries with major infrastructure projects allocated to emerging markets listed companies.

There is the opportunity for a synergy between inside directors and GRDs working jointly together. This paper has seen that listed firms in industries with major projects can benefit from the presence of GRDs reflecting resource dependence and institutional theory. Directors with government influence and access is important for companies, not just for their information and potential access, but also for the legitimacy they give (Pfeffer \& Salancik, 1978). According to Hillman et al. (2000, p. 246) 'Regulation is, at its most basic level, a tie with the government-a link to legitimacy'. Complimentary to GRDs presence on the board, inside directors are an important source of firm-specific knowledge applying stewardship theory. This paper has noticed that inside director presence in the boardroom can enhance the overall effectiveness of the board of directors (Nicholson \& Kiel, 2007). Agency theorists see inside directors in the voting and numerical minority on the board as being a valuable firm resource (Boyd et al., 2011). By aligning the assumption of resource dependence and institutional theory in relation to the role of government representative directors (Hillman et al., 2000) with stewardship theory views on the value of inside directors (Krause et al., 2014) there is the opportunity for a joint multiplicative effect. Hence:

P6: The presence of one or more inside directors in the minority on the board working jointly with GRDs in companies in industries with major infrastructure projects predict firm performance in emerging markets listed companies in a positive relationship.

\section{Discussion and Conclusion}

This paper has been inspired by the knowledge that applying advanced stock market corporate governance theory in an emerging markets context without considering the unique business and social aspects of those countries can limit the quality of the theoretical contribution (Wright et al., 2005). Sensitivity to context is particularly crucial for theory development in this corporate governance context in an emerging market area (Fan 
et al., 2011). According to the contextualist approach (Gergen, 2001) pattern of meaning is rooted in the context, with a need to appreciate the importance of where and when the practice of corporate governance happens. Whetten (1989) has explained that 'observations are embedded and must be understood within a context' ( $\mathrm{p}$. 492). So the context of a country is an important consideration when developing theory on corporate governance in a particular emerging market country. What may work in a corporate governance context such as Australia or the United Kingdom may not necessarily apply in an emerging country with different business, economic, social and legal conditions. So the propositions developed here are informed by agency, hegemony, institutional, resource dependence and stewardship theory specific to the situation for the unique emerging markets business, economic, social and legal context.

On balance considering the arguments presented here agency theory has a limited role in emerging markets business practice, limited to the use of government representatives on listed company boards. The issue of trust has more impact on work practices in emerging markets societies than in Western Anglo-American countries (Floyd, 1999). To limit this risk of a breach of trust, large proportion of the listed firms those markets are owned and controlled by the founding families with independent and outside directors often owing their position to some family affiliation. This set of circumstances in emerging markets business and society limits the value of agency theory and has relevance to other emerging markets where legal statutes and legal precedent established in law courts is not mature and doing business with family affiliates encourages trust (Phan, 2001).

Hegemony theory (Davis et al., 2003) is prominent and influential in the emerging markets business context given the practical role of the ruling elites in enhancing firm performance. Considering that the vast majority of emerging countries are ruled or effectively controlled by a single political party in partnership with socially influential individuals, the paper has seen that firms with outside directors from the those categories benefit from the privileged political and social status of those directors, and are able to lobby for access to major projects allocated by the government. So theoretically by extension countries with a single political party and/or a privileged section or region of society active in business and economic life, holding board positions on companies will be able to use their high social esteem to lobby for access to major government or perhaps private sector funded projects. This will result in favourable financial performance when major government funded projects are allocated to these socially well-connected companies.

Institutional theory has a vital position in corporate governance practices in emerging markets. The ruling class and founding families are a notable, esteemed and influential institution in emerging countries with much influence in all walks of life. In practice, the government is an important institution and its representatives have an important role monitoring government funded investments and projects. Their influence on the economic, business and social scene cannot be underestimated. Government representative directors can provide information, potential access to key public servants and politicians, and lend legitimacy to firms (Hillman et al., 2000 ,). Equity markets also have a new and important institutional role in the emerging countries business and economic scene. The evolution of the legal system and legal precedent in courts of law, regulation of the stock exchange and oversight of director's duties will be interesting to watch in future years. In theory these observations are applicable in across emerging market contexts where there is a single-party rule, major government funded projects and/or investment in listed companies, an emerging stock market supported by an emerging legal system of statutes and courts (Whetten, 2009).

Resource dependence theory has been evidenced to apply in relation to the role of government representatives on boardrooms who can provide a useful source of information and advice. The resource dependence role of outside directors and independent directors remains in practice, despite the inclination for founding families to make family affiliated appointments. This family affiliation does not preclude outside and independent directors assisting the organization in accessing financial, legal or consulting resources. In an emerging market context, this resource dependence role could reasonably be expected to apply (Xu \& Meyer, 2013).

Stewardship theory also has a positive place in corporate governance practice in emerging markets. On balance in theory and practice the paper argues that both native and foreign inside directors have an important positive role as effective stewards of company resources whose interests align with shareholders with majority ownership. Well trained and experienced inside directors are trustworthy, well informed on company strategy, good stewards of resources and gain much personal satisfaction from their contribution and commitment to the firm (Donaldson and Davis, 1991; Krause et al., 2014). The paper argues that considering the evidence stewardship theory applies equally to inside directors in advanced stock market and the emerging stock market context.

\subsection{Limitations}

A potential limitation of this paper is that the insights presented have been informed by corporate governance 
literature generally applied to emerging markets context, leaving some of the propositions presented here helpful to many national settings in emerging markets but not necessarily to all. For example the proposition in relation to outside directors from influential region or ethnicity with social, economic and political status is not applicable for countries where those status do not have an influence on the political or economic scenes. However, regional or ethnic status can be substituted by other social stratifications such as religious or gender status as applicable. Hence, the propositions presented here need to be carefully considered in combination with the context of emerging countries when seeking to adapt the theory presented in this paper to theory development or practice.

\subsection{Future Research}

Withers et al. (2012) and Johnson et al. (2013) have observed that a multi-theoretic approach will lead to a more comprehensive understanding of the relationship between board composition and firm performance. The value of inside directors to stock exchange listed companies in particular is under researched in advanced and emerging markets and requires more empirical insight. Most theory development in corporate governance has been conducted in the advanced economies context, leaving little or no consideration for emerging markets unique social, political, and economic contexts (Phan, 2001; Xu \& Meyer, 2013). The theory development presented here takes a step towards conducting an empirical investigation based on multiple theoretical approaches in an emerging market drawing on agency, hegemony, resource dependence, and stewardship theories. This has the potential to lead to a useful empirical contribution to the literature with future research, examining the research propositions presented here perhaps by developing an archival quantitative data set, qualitative interviews and/or a case study. These research propositions can also be adapted to other emerging markets (Whetten, 2009; Kearney 2012). This is a substantial future research agenda.

\subsection{Conclusion}

Emerging countries are fascinating with their unique business, economic, legal and social context generally impacting strategy and management and specifically corporate governance practices on their emerging stock markets. This paper has set out to better understand the relationship between organizational governance, board of directors and firm performance in emerging markets context and then extend that insights to vital incorporation between contexts with their own unique business, economic, legal, social conditions with corporate governance codes and standards.

\section{Note}

Note 1. The focus of this paper is on the emerging markets of the BRICS (Brazil, Russia, India, China and South Africa), MINT (Mexico, Indonesia, Nigeria and Turkey), the Next Eleven, or markets in Latin America, Eastern Europe, Asia and Africa.

\section{References}

Al-Hussain, A. (2009). Corporate Governance Structure Efficiency and Bank Performance. Phoenix: University of Phoenix Press.

Ali, A. (2008). Business and Management Environment: Challenges and Opportunities for Multinational Corporations. Routledge, London.

Allen, F. (2005). Corporate Governance in Emerging Economies. Oxford Review of Economic Policy, 21, 164-177. http://dx.doi.org/10.1093/oxrep/gri010

Al-Majed, F. (2008). A Conceptual Framework for Reforming the Corporate Governance of Publicly Held Companies: a Comparative and Analytical Study from a Legal Perspective. SABIC Publications, Riyadh.

Al-Matari, Y., Al-Swidi, A., \& Fadzil, F. (2012). Corporate Governance and Performance of Saudi Arabia Listed Companies. British Journal of Arts \& Social Sciences, 9, 1-30. http://dx.doi.org/BJASS_9_1/BJASS_09_01_01

Al-Rasheed, M. (2010). A History of Saudi Arabia. Cambridge: Cambridge University Press.

Al-Twaijry, A. (2007). Saudi Stock Market Historical View and Crisis Effect: Graphical and Statistical Analysis. Journal of Human Science, 5, 1-31. http://dx.doi.org/10.1111/1467-8683.00293

Bazerman, M., \& Schoorman, F. (1983). A Limited Rationality Model of Interlocking Directorates. Academy of Management Review, 8, 206-217. http://www.jstor.org/stable/257747

Boyd, B., Haynes, K., \& Zona, F. (2011). Dimensions of CEO-Board Relations. Journal of Management Studies, 48, 1892-1923. http://dx.doi.org/10.1111/j.1467-6486.2010.00943.x 
Bray, B., \& Darlow, M. (2013). Ibn Saud: The Desert Warrior Who Created the Kingdom of Saudi Arabia. New York: Skyhorse Publishing.

Burris, V. (2005). Interlocking Directorates and Political Cohesion among Corporate Elites. American Journal of Sociology, 111, 249-283. http://dx.doi.org/10.1086/428817

Claessens, S., \& Yurtoglu, B. (2013). Corporate Governance in Emerging Markets: A Survey. Emerging Markets Review, 15, 1-33. http://dx.doi.org/10.1016/j.ememar.2012.03.002

CMA. (2012). Annual Report-2012. Capital Market Authority Publications, Riyadh.

Coles, J., McWilliams, V., \& Sen, N. (2001). An Examination of the Relationship of Governance Mechanisms to Performance. Journal of Management, 27, 23-50. http://dx.doi.org/10.1177/014920630102700102

Dalton, D., Daily, C., Ellstrand, A., \& Johnson, J. (1998). Meta-Analytic Reviews of Board Composition, Leadership Structure, and Financial Performance. Strategic Management Journal, 19, 269-290. http://dx.doi.org/10.1002/(SICI)1097-0266(199803)19:3<269::AID-SMJ950>3.0.CO;2-K

Davies, A. (2012). The Globalisation of Corporate Governance: The Challenge of Clashing Cultures. Gower Publishing Ltd, Surrey.

Davis, G., Yoo, M., \& Baker, W. (2003). The Small World of the American Corporate Elite, 1982-2001. Strategic Organization, 31, 301-326. http://dx.doi.org/10.1177/14761270030013002

Donaldson, L., \& Davis, J. (1991). Stewardship Theory or Agency Theory: CEO Governance and Shareholder Returns. Australian Journal of Management, 16, 49-64. http://dx.doi.org/10.1177/031289629101600103

Ezzine, H. (2012). A Cross Saudi Firm Analysis the Impact of Corporate Governance on the Stock Price Performance during the Recent Financial Crisis. SABIC Publications, Riyadh.

Fan, J. P., Wei, K. C., \& Xu, X. (2011). Corporate Finance and Governance in Emerging Markets: A Selective Review and an Agenda for Future Research. Journal of Corporate Finance, 17, 207-214. http://dx.doi.org/10.1016/j.jcorpfin.2010.12.001

Floyd, D. (1999). Eastern and Western Management Practices: Myth or Reality? Management Decision, 37, 628-632. http://dx.doi.org/10.1108/00251749910291596

Gergen, K. (2001). Social Construction in Context. London: Sage Publications.

Hillman, A., Cannella, A., \& Paetzold, R. (2000). The Resource Dependence Role of Corporate Directors: Strategic Adaptation of Board Composition in Response to Environmental Change. Journal of Management Studies, 37, 235-256. http://dx.doi.org/10.1111/1467-6486.00179

Hoskisson, R., Eden, L., Lau, C., \& Wright, M. (2000). Strategy in Emerging Economies. Academy of Management Journal, 43, 249-267. http://dx.doi.org/10.2307/1556394

Huse, M., Hoskisson, R., Zattoni, A., \& Vigano, R. (2011). New Perspectives on Board Research: Changing the Research Agenda. Journal of Management \& Governance, 15, 5-28. http://dx.doi.org/10.1007/s10997-009-9122-9

Jensen, M., \& Meckling, W. (1976). Theory of the Firm: Managerial Behavior, Agency Costs and Ownership Structure. Journal of Financial Economics, 3, 305-360. http://dx.doi.org/10.1016/0304-405X(76)90026-X

Johnson, J., Ellstrand, A., \& Daily, C. (1996). Boards of Directors: A Review and Research Agenda. Journal of Management, 22, 409-438. http://dx.doi.org/10.1177/014920639602200303

Johnson, S., Schnatterly, K., \& Hill, A. (2013). Board Composition Beyond Independence Social Capital, Human Capital, and Demographics. Journal of Management, 39, 232-262. http://dx.doi.org/10.1177/0149206312463938

Karolyi, G. A. (2012). Corporate Governance, Agency Problems and International Cross-Listings: A Defense of the Bonding Hypothesis. Emerging Markets Review, 13, 516-547. http://dx.doi.org/10.1016/j.ememar.2012.08.001

Kearney, C. (2012). Emerging Markets Research: Trends, Issues and Future Directions. Emerging Markets Review, 13, 159-183.

Khanna, T., \& Thomas, C. (2009). Synchronicity and Firm Interlocks in An Emerging Market. Journal of Financial Economics, 92, 182-204. http://dx.doi.org/10.1016/j.ememar.2012.01.003

Klapper, L., \& Love, I. (2004). Corporate Governance, Investor Protection, and Performance in Emerging 
Markets. Journal of Corporate Finance, 10, 703-728. http://dx.doi.org/10.1016/j.jfineco.2008.03.005

Krause, R., Semadeni, M., \& Cannella, A. (2014). CEO Duality-A Review and Research Agenda. Journal of Management, 40, 256-286. http://dx.doi.org/10.1177/0149206313503013

Mallin, C. (2013). Corporate Governance. Oxford University Press, Oxford.

Marquis, C., \& Raynard, M. (2015). Institutional Strategies in Emerging Markets. The Academy of Management Annals, 9, 291-335. http://dx.doi.org/10.1080/19416520.2015.1014661

Millar, C., Eldomiaty, T., Choi, C., \& Hilton, B. (2005). Corporate Governance and Institutional Transparency in Emerging Markets. Journal of Business Ethics, 59, 163-174. http://dx.doi.org/10.1007/s10551-005-3412-1

Mueller, D. (2006). The Anglo Saxon Approach to Corporate Governance and its Applicability to Emerging Markets. Corporate Governance: An International Review, 14, 207-219.

Niblock, T., \& Malik, M. (2007). The Political Economy of Saudi Arabia. Routledge, New York.

Nicholson, G., \& Kiel, G. (2007). Can Directors Impact Performance? A Case-Based Test of Three Theories of Corporate Governance. Corporate Governance: An International Review, 15, 585-608. http://dx.doi.org/10.1111/j.1467-8683.2007.00590.x

Oukil, M., \& Al-Khalifah, H. (2012). Managerial Weaknesses and Features of Family Businesses in the Eastern Region of Saudi Arabia. International Conference on Economics, Business and Marketing Management, 29, 49-54. http://dx.doi.org/74274180

Peng, M. (2004). Outside Directors and Firm Performance During Institutional Transitions. Strategic Management Journal, 25, 453-471. http://dx.doi.org/10.1.1.126.2347

Perrow, C. (1986). Complex Organizations: A Critical Essay. New York: McGraw-Hill.

Pfeffer, J. (1972). Size and Composition of Corporate Boards of Directors. Administrative Science Quarterly, 17, 218-229. http://dx.doi.org/10.2307/2393956

Pfeffer, J., \& Salancik, G. (1978). The External Control of Organizations: A Resource Dependence Perspective. New York: Harper and Row.

Phan, P. (2001). Corporate Governance in The Newly Emerging Economies. Asia Pacific Journal of Management, 18, 131-136. http://dx.doi.org/10.1023/A:1010630320396

Reed, J. (2009). The Saudi Royal Family. New York: Infobase Publishing.

Sarayrah, Y. (2004). Servant Leadership in the Bedouin-Arab Culture. Global Virtue Ethics Review, 5, 58-79. http://dx.doi.org/1P3-1011232771

Solomon, J. (2011). Corporate Governance and Accountability. John Wiley \& Sons, Sussex.

The World Bank. (2009). Corporate Governance Country Assessment-Kingdom of Saudi Arabia. Retrieved from http://www.worldbank.org/ifa/rosc_cg.html

The World Bank. (2013). The World Bank Indicators for Economy and Growth. Retrieved from http://data.worldbank.org/indicator/BX.KLT.DINV.CD.WD

Useem, M. (1984). The Inner Circle. New York: Oxford University Press.

Whetten, D. (1989). What Constitutes a Theoretical Contribution? Academy of Management Review, 14, 490-495. http://dx.doi.org/10.5465/AMR.1989.4308371

Whetten, D. (2009). An Examination of the Interface Between Context and Theory Applied to the Study of Chinese Organizations. Management and Organization Review, 5, 29-55. http://dx.doi.org/10.1111/j.1740-8784.2008.00132.x

Withers, M., Hillman, A., \& Cannella, A. (2012). A Multidisciplinary Review of the Director Selection Literature. Journal of Management, 38, 243-277. http://dx.doi.org/10.1177/0149206311428671

Wright, M., Filatotchev, I., Hoskisson, R., \& Peng, M. (2005). Strategy Research in Emerging Economies: Challenging the Conventional Wisdom. Journal of Management Studies, 42, 1-33. http://dx.doi.org/10.1111/j.1467-6486.2005.00487.x

Xu, D., \& Meyer, K. E. (2013). Linking Theory and Context: 'Strategy Research in Emerging Economies' after Wright et al. 2005. Journal of Management Studies, 50, 1322-1346. http://dx.doi.org/10.1111/j.1467-6486.2012.01051.x 
Young, M., Peng, M., Ahlstrom, D., Bruton, G., \& Jiang, Y. (2008). Corporate Governance in Emerging Economies: A Review of the Principal-Principal Perspective. Journal of Management Studies, 45, 196-220. http://dx.doi.org/10.1111/j.1467-6486.2007.00752.x

Zahra, S., \& Pearce, J. (1989). Boards of Directors and Corporate Financial Performance: A Review and Integrative Model. Journal of Management, 15, 291-334. http://dx.doi.org/10.1177/014920638901500208

\section{Copyrights}

Copyright for this article is retained by the author(s), with first publication rights granted to the journal.

This is an open-access article distributed under the terms and conditions of the Creative Commons Attribution license (http://creativecommons.org/licenses/by/3.0/). 